Research Article

\title{
Consumer Preferences toward Goat Milk
}

Yohana Agustina1, Jangkung Handoyo Mulyo², Lestari Rahayu Waluyati ${ }^{3}$, M. Zul Mazwan ${ }^{4}$

a,d Program Studi Agribisnis, Fakultas Pertanian-Peternakan, Universitas Muhammadiyah Malang, Jl. Raya Tlogomas No. 246, 64141, Indonesia

b,c Program Studi Magister Manajemen Agribisnis, Fakultas Pertanian Yogyakarta, Universitas Gadjah Mada, Jl. Flora, 55821, Indonesia

1yohana.a@umm.ac.id *, ${ }^{2}$ hhandoyom@gmail.com, 3lestarirahayu wlyt@yahoo.co.id, ${ }^{4}$ mzulmazwan@umm.ac.id

* corresponding author

\begin{tabular}{|c|c|}
\hline ARTICLE INFO & ABSTRACT \\
\hline $\begin{array}{l}\text { Article history } \\
\text { Received March 08, } 2021 \\
\text { Revised October 09, } 2021 \\
\text { Accepted October 23, } 2021 \\
\text { Published October 29, } 2021 \\
\text { Keywords } \\
\text { Goat Milk Powder } \\
\text { consumer preferences } \\
\text { Conjoint analysis }\end{array}$ & $\begin{array}{l}\text { The high level of business competition in this current globalization requires } \\
\text { companies to produce quality products. Among the efforts of product improvement is } \\
\text { through understanding consumer preferences. This study aims to identify consumer } \\
\text { preferences of several attribute combinations of goat milk branded Bumiku Hijau, } \\
\text { Yogyakarta. Conjoint analysis with pairwise-comparison was employed in this study. } \\
\text { The combination of attributes analyzed were price, flavor variant, types of milk, and } \\
\text { packaging. Results showed that the best combination results were obtained on stimuli } \\
\text { number } 13 \text { with a total usability value of } 3.709 \text {, which was } 0.356 \text { on the product price. } \\
\text { The chocolate flavor variant attributes to the largest total usability value of } 0.166 \text {. } \\
\text { Based on the type of milk, the total usability value of powdered milk (skim) is } 0.073 \text {, } \\
\text { and the highest usability value was obtained through carton packaging (200gr) of } \\
\text { 0.077. Consumers favored powdered goat milk products with new flavor variants that } \\
\text { suit teenagers and adults. They also want } 100 \text { gr product packaging as it is easier to } \\
\text { measure and consume. } \\
\text { This is an open access article under the CC-BY-SA license }\end{array}$ \\
\hline
\end{tabular}

\section{INTRODUCTION}

The current globalization era has sent businesses and industries to undergo tight competition. This requires companies to create meaningful innovations to maintain existence and sustainability over time. Hence, companies must understand consume's desire for the products (Resmawati et al., 2013). Among the strategies are conducting market research that connects consumers, customers, and the wider public with marketers.

Milk processing is among the industries that is currently growing rapidly and competitively in Indonesia. The processing industry includes the production of powdered milk, sweetened condensed milk, sour milk, and milk cream, including its preservation, such as sterilization and pasteurization. The promising market potential to boost profit is milk processing industry and its derivative products (Holmes et al., 2016).

Milk is a source of complete nutritions needed by human body (Bytyqi et al., 2020; Phan et al., 2020; Sugrová, 2018). However, the Pusat Data dan Sistem Informasi Pertanian (2019) states that the level of consumption of liquid milk in Indonesia is 11.09 liters/capita/year. Such increase is relatively low compared to several countries in ASEAN whose average consumption level reaches 20 liters/capita/year. 
The low level of milk consumption in Indonesia is visible from the type of milk product that dominates the market share in Indonesia. Various dairy products that dominate the market share include 40\% sweetened condensed milk, 40\% powdered milk, and 20\% liquid milk (Widaryanti \& Retnaningsih, 2018). Indonesians assume that all types of dairy products - both pure milk and its derivative products - have the same nutritional quality. This makes consumers prefer to consume processed milk products, in the form of sweetened condensed milk or milk powder, than consuming whole milk. This preference is based on taste and long shelf life compared to whole milk ready for consumption.

In addition to cow milk - which dominates Indonesian dairy industry market - goat milk is an alternative with equal nutritional content and benefits, and offers a solution for those allergic to cow milk. Goat milk is produced by female goats after giving birth. Within 0-3 days, its colostrum contains many nutrients and are the best source of protein, even almost equivalent to breast milk. Goat milk is also potential for medicine and improve body nutrients (Ranadheera et al., 2019).

The price of goat milk is higher than cow milk, driven by the goat business. Etawa breed, especially, is a promising business prospect in the long term (Tarigan et al., 2020). Yogyakarta in Central Java, Indonesia, has a fairly high population growth of the Etawa crossbreed. This crossbreed is well-adapting to Indonesian climate with affordable maintenance costs (Prihanani et al., 2020). As milk producers, goat holds $60 \%$ more than meat producers. Maesya \& Rusdiana (2018) noted that a prospective increase in demand for goat products in Indonesia will potentially take place in the next 10 years.

Previous research on consumer preferences for dairy products (pure milk, processed cow milk, and processed goat milk) has been widely carried out. There are research on consumer behavior in buying dairy products (Bytyqi et al., 2020; Šugrová, 2018), the influencing factors on consumers' purchasing behaviors of milk products (Kaliji et al., 2019; Shunekeyeva, 2020), consumers' preference towards goat milk (Fanani \& Thohari, 2018; Guney \& Ocak, 2013; Solikah \& Dewi, 2016), impacts of brands on consumers' decision (Kishokumar \& Suganya, 2019; Velcovská \& Larsen, 2021; Wijesinghe et al., 2020), and quality evaluation on production process of the powdered goat milk (Widodo et al., 2012).

A prevalent similarity emanates from these studies where none analyzed consumer preferences for dairy products between pure and powdered goat milk. Research on the quality control of the raw materials of powdered goat milk conducted by Agustina and colleagues (2020) did not explain in detail about consumers' preference for different types of goat milk.

Bumiku Hijau is a dominating goat milk producer in Yogyakarta since 2007. The company produces various processed goat milk, including pasteurized, powdered goatmilk, yoghurt, ice cream, and goat kefir. Their products are of high quality and benefits with prospective selling value. However, many people do not realize the benefits of powdered goat milk.

Based on this background, it can be said that there is less information on the literature about consumer preferences between pure and powdered goat milk. This present study aims to study consumers' preferences on goat milk. It analyzed consumers' decision process, and the attributes of their main considerations in purchasing goat milk from Bumiku Hijau Yogyakarta.

\section{METHODOLOGY}

This present study took place in Bumiku Hijau, a producer of pure goat milk and its derivative products, namely powdered goat milk with various flavors (original, chocolate, and vanilla) in Yogyakarta. Bumiku Hijau was chosen through purposive sampling method as it dominates the market share in Yogyakarta. This company consistently develops products by producing various flavors of powdered goat milk.

The stages of the research included preliminary survey, identification of variables, data collection of research samples, and conjoint analysis. The variables used in this present study are attributes consisting of several levels. Product attributes are the elements considered important by the customers, which serve as the basis for decision making (Hidayat et al., 2012; Tekea, 2021).

Accordingly, preference is the evaluation outcome of several product attributes including the type of product, characteristics, organoleptic, and product benefits to consumer health (Fanani \& Thohari, 2018). The preference itself is generally influenced by consumer motivation that comes from internal and external factors. Variable identification consists of characteristics in a product, and would be analyzed using the Conjoint method consisting of price attributes, flavor variants, types of milk, and packaging. These attributes act as the basis of an initial survey of consumer considerations in buying dairy products from Bumiku Hijau Yogyakarta. The attributes used in this study are as follows: 
Table 1. Identification of attributes of goat milk produced by Bumiku Hijau

\begin{tabular}{ll}
\hline \multicolumn{1}{c}{ Attribute } & \multicolumn{1}{c}{ Level } \\
\hline Price & 1. IDR 15,000 \\
& 2. IDR 25,000 \\
Flavor variants & 1. Original \\
& 2. Vanilla \\
& 3. Chocolate \\
Type of milk & 1. Pasteurized \\
& 2. Powdered (Skim) \\
Packaging & 1. Bottle (330ml) \\
& 2. Carton (200 gr) \\
\hline
\end{tabular}

Conjoint analysis is a multivariate technique used specifically to find out consumers' preference over a product. This type of analysis could also get the combination or composition of the attributes of a product in the form of new products, or products that have been circulating in the market favorable by the consumers. Attributes are elements contained in a product to describe the character of a product under study.

Sampling was done intentionally (purposive sampling) with random sampling. The sample in this study were consumers of Bumiku Hijau who purchased pasteurized and powdered goat milk. The criteria for consumption are at least twice in the last month, and aged over 17 years. According to Yasmin and colleagues (2017), the recommended number of samples in research using the Conjoint analysis method is between 50 to 100 samples. In this study, the samples were 100 respondents per April 2020.

The next stage in this research is to form product combination stimuli from predetermined attribute levels as presented in Table 1. The formation of combination stimuli is obtained by combining attribute levels into a stimulus or profile formed to analyze the research data through SPSS 17.0 software for Windows.

The combination of stimuli was used to obtain respondents' assessment on the best combination of attributes based on their preferences. The combination of stimuli was $2 \times 3 \times 2 \times 2$ in order to obtain 24 stimuli. However, this study did not display entirely in the questionnaire because it was deemed too much. Therefore, 16 main stimuli were used based on the formation.

The data of this study were based on consumer ratings on attribute combinations, starting from the combination stimulation number 1 to number 16 with a score rating on the Likert scale, presented as follows:

Table 2. Likert scale for the questionnaire

\begin{tabular}{lc}
\hline \multicolumn{1}{c}{ Statement } & Score \\
\hline Highly favorable (HF) & 5 \\
Favorable (F) & 4 \\
Average (A) & 3 \\
Not favorable (NF) & 2 \\
Highly unfavorable (HU) & 1 \\
\hline
\end{tabular}

Results of the respondent's assessment of the combination of attributes were used to process consumer preference data using the conjoint method. Consumer ratings on 16 combination stimuli processed using conjoint analysis to study the utility value of each attribute, the total usability value, and the level of attribute importance. The usability value is generated from consumer assessments, indicating the level of consumer preference with a positive value refers to the high preference. As the opposite, a negative value indicates a lower level of consumer preference (Ong et al., 2021).

Following this, the total usability value was obtained to determine which attribute combination is the best based on the conjoint calculation. The calculation of the total usability value in the Conjoint method is presented as follows:

$$
\mu(x)=A_{0}+\sum_{i=1}^{m} \sum_{j=1}^{k} a_{i j} x_{i j}
$$


note:

$\mu(x) \quad=$ usability value of each profile

$A_{0} \quad=$ average constant value from consumers' assessment on each

profile

$X_{\mathrm{ij}} \quad=$ independent variable in the forms of I attribute and $\mathrm{j}$ level

$\mathrm{M} \quad$ = amount of attribute

$\mathrm{N} \quad=$ amount of level in each attribute

After calculating the total usability value to get the best combination stimuli of attributes, the level of attribute importance was obtained by calculating the percentage.

\section{FINDINGS AND DISCUSSION Company profile}

Bumiku Hijau has its own farm in Yogyakarta, and the business was founded in 2003 under the management of CV Barokah Adhiniaga Firdaus (CV BAF). The company has relied its development on increasing the number of Etawa crossbreeds along with the increasing public demand for goat milk. Seeing the development and business prospects of Etawa crossbreed goats and goat milk, the business stood alone in November 2010, named in Bumiku Hijau. Its activities include goat breeding, producing and selling Etawa crossbreed goats, and selling Etawa crossbreed goat milk and its processed products.

Etawa crossbreed goat has high potential to develop in Indonesia (Pristawati \& Fikri, 2021). Hence in 2010, pure Etawa crossbreed goat milk and its variations (i.e., ice cream) are sold through the goat milk shop located in Jalur Lingkar Utara. Bumiku Hijau also provides delivery services. In early 2010, the number of livestock in Bumiku Hijau increased to 188 located in Jalur Lingkar Utara, Sayegan, and Magelang. In 2018, the total number of livestock reached more than 275 in those three locations. In Magelang alone, there are more than 125 sheep.

Bumiku Hijau's goat milk has gradually increased along with consumer orders and direct buyers on the shop. Consumers come from Yogyakarta, Muntilan, Magelang, Kebumen, Semarang, Kudus, Temanggung, Wonogiri, Solo, Jakarta, Sumatra, and Kalimantan. Consumers from outside Yogyakarta come directly to the shop or order online. The intercities expedition is carried out through a freight forwarder. Bumiku Hijau provides delivery services to customers in Yogyakarta with a minimum purchase of five bottles of milk.

Pure whole milk is bottle-packaged in a size of $330 \mathrm{ml}$ for IDR 15,000 per bottle and 1 liter for IDR 39,000 per bottle. Goat colostrum milk is packaged in $330 \mathrm{ml}$ bottles at a price of IDR 50,000 per bottle. Ice cream is packaged in cups for IDR 3,500 per cup. The price was determined following the market price with the principle that the total costs incurred are below the market price. The results would be the selling price by Bumiku Hijau. Discounts are given to consumers who buy more than ten bottles of goat milk, at a price of IDR 13,000 per bottle. The payment system is done by cash.

The $330 \mathrm{ml}$ goat milk is sold at the company's shop, and is also sold at the food stores and individuals as agents in its sales. The marketing channel is through direct selling and selling agents. A total of twelve agents selling Bumiku Hijau products in Yogyakarta, spread across Bantul (two agents), Ngampilan (one agent), Casagrande (one agent), Pathuk (one agent), Godean (two agents), Kotagede (one agent), Glagahsari (one agent), Wirobrajan (one agent), Jalan Solo (one agent), and Jalan Monjali (one agent).

Consumers' convenience in purchasing has become a primary concern for Bumiku Hijau. They are currently running a selling point named Kedai Susu Kambing, making it easy for consumers to get their products. To get closer to consumers, the company provides ready-to-delivery services. Bumiku Hijau guarantees that the goat milk received by the end-users remains in good condition. The delivery service is carried out using a styrofoam box to keep the milk frozen for 24 hours and in good quality. The distribution is carried out from Bumiku Hijau directly to the final consumer.

Bumiku Hijau promotes its business through brochures in city centers and places visited by many people. In addition to distributing brochures, the company also promote through the internet, advertisements in mass and electronic media, including banners and billboards. Bumiku Hijau also participates in several food and livestock product exhibition events held by the department or university. The goal is to encourage consumers 
who are not familiar with goat milk products to become familiar, understand, and confident to buy the products.

\section{The characteristics of consumers of Bumiku Hijau}

Demographic factors such as gender, age, and education level greatly affect the acceptability of functional food ingredients, as well as the benefits of these foods on health. Table 3 shows that the majority of purchases of milk produced by Bumiku Hijau are dominated by female consumers as much as $64 \%$, while male consumers are $36 \%$. This happens because women tend to have a higher consumptive nature than men. In line with the opinion from Nugroho and colleagues (2020), female consumers - especially housewives - play a critical role in determining and deciding foodstuffs consumed by their family members. The majority of respondents are between 31-40 years old with a percentage of $47 \%$. This is in line with Ratnamentari and collaegues (2016) who states that the majority of goat milk's consumers is between 30-50 years old.

In that age range, one will always try to meet protein needs both for himself and his family. Most of the respondents' education levels are undergraduate with a total of $44 \%$. This is in line with Pristawati \& Fikri (2021) who state that the respondent's education level affects knowledge of dairy products in general. Characteristics of respondents based on gender, age, and education level are shown in the following table:

Tabel 3. The characteristics of consumers of goat milk

\begin{tabular}{|c|c|c|c|}
\hline No & Characteristic & Number (in person) & Percentage (\%) \\
\hline \multirow[t]{4}{*}{1} & Gender & & \\
\hline & Female & 64 & 64 \\
\hline & Male & 36 & 36 \\
\hline & & 100 & 100 \\
\hline \multirow[t]{6}{*}{2} & Age group (year-old) & & \\
\hline & $20-30$ & 22 & 22 \\
\hline & $31-40$ & 47 & 47 \\
\hline & $41-50$ & 23 & 23 \\
\hline & $>50$ & 8 & 8 \\
\hline & & 100 & 100 \\
\hline \multirow[t]{7}{*}{3} & Education level & & \\
\hline & Primary school & 11 & 11 \\
\hline & Junior high school & 22 & 22 \\
\hline & Senior high school & 13 & 13 \\
\hline & Bachelor/ undergraduate & 44 & 44 \\
\hline & Master & 10 & 10 \\
\hline & & 100 & 100 \\
\hline
\end{tabular}

Source: analyzed primary data, 2020

\section{Correlation test of research data}

Consumer preferences for goat milk were analyzed using conjoint analysis with a pairwise approach. The attributes of goat milk included price, flavor variant, type of milk, and packaging. In making purchases of a processed food product, consumers cannot be separated from the view of the attributes that exist in food, which will affect their preferences (Tuan et al., 2013). This correlation test aimed to determine the relationship between the research data, namely the combination of attributes with consumer preferences for Bumiku Hijau goat milk products. The correlation test was carried out by analyzing the product moment correlation, which was the Pearson's $r$ value and the sig. value. The results of the correlation test of the research data are presented as follows: 
Table 4. Results of the correlation test of research data

\begin{tabular}{lrr}
\hline \multicolumn{1}{c}{ Criteria } & Value & \multicolumn{1}{c}{ Sig. } \\
\hline Pearson's $r$ & .918 & .000 \\
Kendall's tau & .701 & .000 \\
Kendall's tau for Holdouts & 1.000 & - \\
\hline Source: analyzed primary data, 2020 & &
\end{tabular}

Table 3 shows a relationship between the combination of attributes and consumer preferences based on Pearson's $r$ value with 0.918 . The value of consumer preferences influences as much as $91.8 \%$. this indicates a very strong correlation level supported by a significance value of 0.000 . This number signifies strong value as it does not exceed the significant level used, which is 0.05 . A correlation between 0.80 and 1.00 is very strong between preferences and the data obtained (Jin et al., 2019).

\section{The utility value on each attribute level based on consumers' preference}

The utility value describes each respondent's opinion in numbers as the basis for determining the level of satisfaction (Shingh et al., 2020; Velcovská \& Larsen, 2021). In the study of consumer preference on goat milk using the conjoint method, the usability value describes the consumer's assessment of each attribute level with positive numbers and negative numbers. The positive and largest values indicate the level of the attribute that is most preferable, while the negative value means that consumers do not like it much. The utility value at each attribute level based on consumer preferences can be seen in the table below:

Table 5. The utility level on each attribute level based on consumers' preference

\begin{tabular}{llrr}
\hline Attribute & \multicolumn{1}{c}{ Attribute level } & $\begin{array}{c}\text { Utility } \\
\text { Estimate }\end{array}$ & Std. Error \\
\hline Price & IDR 15,000 & -0.317 & 0.068 \\
Flavor variants & IDR 25,000 & 0.356 & 0.067 \\
& Original & -0.159 & 0.046 \\
& Vanilla & 0.145 & 0.043 \\
Types of milk & Chocolate & 0.166 & 0.046 \\
& Pasteurized & -0.073 & 0.041 \\
Packaging & Powdered (Skim) & 0.073 & 0.041 \\
& Bottle (330ml) & -0.057 & 0.048 \\
& Carton (200gr) & 0.077 & 0.048 \\
& (Constant) & 3.709 & 0.047
\end{tabular}

Source: analyzed primary data, 2020

In the usability value analysis, there are four attributes of goat milk that are assessed, namely price, flavor variant, type of milk, and packaging. Based on the usability value obtained, the product attributes ranging from the most desirable to the less attractive are price attributes, flavor variants, packaging, and types of milk.

\section{Attribute of price}

The price attribute is the main consideration for consumers in purchasing goat milk products. Based on the table above, it is shown that consumer preferences for goat milk attributes, namely powdered milk type for vanilla and chocolate flavor variants, for IDR 25,000 with 200 gram carton packaging. The price attribute has the highest usability value as a preference, followed by flavors, packaging and types of milk. This shows that consumers prefer goat milk products at a price of IDR 25,000 as indicated by a positive number on the usability value of 0.356 and accepted by consumers.

In terms of price, although consumers have to pay more expensive products than powdered milk, they did not seem to mind because powdered goat milk have a variety of flavors. The suitability of product prices went along with the quality, which is rich in nutritional benefits for consumers' health.

\section{Attribute of flavor variants}

The flavor variant attribute has a fairly high utility value after the price attribute. In line with Nugroho and colleagues (2020), consumer decision making shows that the attribute of the flavor variant is an important 
aspect to consider before making a purchase. Out of the three flavors offered in the attribute of the flavor variant (original, vanilla, and chocolate), consumers prefer chocolate and vanilla with a utility value of 0.166 and 0.145 , which are positive, while the utility value of the original taste is negative. This shows that the flavor variants that consumers prefer are different, so that the choice of flavor variants is an important attribute in order to meet consumer needs closer to the portion of consumer preferences.

The variant of chocolate flavor became the main choice of consumers compared to other flavor variants. Results showed that consumers stated that chocolate powdered goat milk chocolate taste better without any goat aroma presented in other flavor variants. These results are in line with Boniface \& Umberger (2012); Kapaj \& Albania (2018); Kurajdova \& Táborecka-Petrovicova (2015); and Yang \& Dharmasena (2020), where the product taste variants influence the purchasing decisions of consumers of dairy products regardless its expensive price.

\section{Attribute of packaging}

Packaging is the third attribute considered by consumers in purchasing Bumiku Hijau goat milk. Although they did not make the form of packaging a top priority, consumers paid attention to the practical side. This is indicated by the packaging attribute where consumers prefer the type of carton size $(200 \mathrm{gr})$ with a utility value of 0.077 , which is positive. This shows that consumers prefer packaging that is more practical than bottled packaging, which of course has a more expensive packaging price.

\section{Attribut of milk type}

The type of goat milk is the last attribute considered by consumers. The type of preferable goat milk is the powdered type compared to the pasteurized type. This follows a study by Santoso and collaegues (2012) who states that more consumers prefer powdered milk than pasteurized milk. Powdered goat milk is more practical for consumers without refrigerator where the remaining powder in the packaging can be consumed at a later date. Consumers prefer powdered milk is also certainly more durable than pasteurized milk which should be consumed within 7 to 10 days.

Results also show that the needs and budget of consumers are among the reasons for choosing the size of the goat milk packaging to suit the needs of family members, and fitting the budget that has been set. For consumers, packaging is a valid attribute (although less considered) because any changes in packaging does not affect consumers' purchasing habit because they can coinsider product prices and flavor variants.

The process of consumer preference for goat milk is the same as for food in the form of consumer goods (food ingredients for daily consumption), namely through a trial stage, which is influenced by marketing or promotion strategies, lifestyle, association, and others. If they experience satisfaction, the consumers will purchase repeatedly.

\section{CONCLUSION}

This study reveals that consumer preferences focus on the results of the best combination of stimuli based on the utility value and the level of importance of the attributes in it. It was found that the best combination results are obtained on stimuli number 13 with a total usability value of 3.709 ; on the product price attribute of 0.356 ; and on the chocolate flavor variant of 0.166 will be obtained. In the attribute of the type of milk, the total usability value of powdered milk (skim) is 0.73 ; and the attribute of the packaging is the carton packaging $(200 \mathrm{gr})$ of 0.77 . Majority of consumers preferred powdered goat milk products with new flavor variants that suit the tastes of teenagers and adults. Consumers also preferred $100 \mathrm{gr}$ product packaging because it is easier to measure and consume. Based on the utility value, the preferred attributes are price, flavor variant, type of packaging, and type of milk. 


\section{REFERENCES}

Agustina, Y., Mulyo, J. H., \& Waluyati, R. (2020). Analisis Pengendalian Mutu Bahan Baku Utama Susu Kambing Bubuk di Bumiku Hijau Yogyakarta. Jurnal Teknosains, 9 (2)(Juni), 91-180.

Boniface, B., \& Umberger, W. J. (2012). Factors Influencing Malaysian Consumers' Consumption of Dairy Products. Australia Agricultural and Resource Economics Society, 1(1), 1-30.

Bytyqi, N., Muji, S., \& Rexhepi, A. (2020). Consumer Behavior for Milk and Dairy Products as Daily Consumption Products in Every Household-The Case of Kosovo. Open Journal of Business and Management, 08(02), 997-1003. https://doi.org/10.4236/ojbm.2020.82063

Fanani, Z., \& Thohari, I. (2018). Preferensi Konsumen Produk Kefir Susu Kambing Di Malang. Jurnal Nusantara Aplikasi Manajemen Bisnis, 3(1), 54. https://doi.org/10.29407/nusamba.v3i1.12029

Guney, I., \& Ocak, S. (2013). Consumer Preference for Goat Milk in Turkey Consumer Preference for Goat Milk in Turkey. Global Advanced Research Journal of Agricultural Science, 2(7), 181-188.

Hidayat, A. T., Mustikasari Elita, F., \& Setiaman, A. (2012). Hubungan Antara Atribut Produk Dengan Minat Beli Konsumen. EJurnal Mahasiswa Universitas Padjajaran, 1(1), 19. http://journals.unpad.ac.id

Holmes, R., Hayes, J., Matthaei, C., Closs, G., Williams, M., \& Goodwin, E. (2016). Riparian Management Affects Instream Habitat Condition in a Dairy Stream Catchment. New Zealand Journal of Marine and Freshwater Research, 50(4), 581-599. https://doi.org/10.1080/00288330.2016.1184169

Jin, S., Yuan, R., Zhang, Y., \& Jin, X. (2019). Chinese Consumers' Preferences for Attributes of Fresh Milk: A Best-Worst Approach. International Journal of Environmental Research and Public Health, 16(21), 116. https://doi.org/10.3390/ijerph16214286

Kaliji, S. A., Mojaverian, S. M., Amirnejad, H., \& Canavari, M. (2019). Factors affecting consumers' dairy products preferences. Agris On-Line Papers in Economics and Informatics, 11(2), 3-14. https://doi.org/10.7160/AOL.2019.110201

Kapaj, A., \& Albania. (2018). Factors That Influence Milk Consumption World Trends and Facts. European Journal of Business, Economi, 6(2), 14-18.

Kishokumar, M. R., \& Suganya, M. K. (2019). Impact of Marketing Mix on Consumer Brand Preference In Milk Powder Industry. IJARIIE, 5(5), 966-973.

Kurajdova, K., \& Táborecka-Petrovicova, J. (2015). Literature Review on Factors Influencing Milk Purchase Behaviour. International Review of Management and Marketing, 5(1), 9-25.

Maesya, A., \& Rusdiana, S. (2018). Prospek Pengembangan Usaha Ternak Kambing dan Memacu $\begin{array}{llll}\text { Peningkatan } \quad \text { Ekonomi } & \text { Peternak. } & \text { Agriekonomika, } & \text { 7(2), }\end{array}$ https://doi.org/10.21107/agriekonomika.v7i2.4459

Nugroho, Y. A., Muksin, \& Setiawan, B. M. (2020). Analisis Preferensi Konsumen Rumah Tangga Terhadap Susu Cair Kemasan di Kecamatan Jateng Kabupaten Karanganyar. Jurnal Undip.

Ong, A. K. S., Prasetyo, Y. T., Libiran, M. A. D. C., Lontoc, Y. M. A., Lunaria, J. A. V., Manalo, A. M., Miraja, B. A., Young, M. N., Chuenyindee, T., Persada, S. F., \& Redi, A. A. N. P. (2021). Consumer Preference Analysis on Attributes of Milk Tea: A Conjoint Analysis Approach. Foods, 10(6), 1-16. https://doi.org/10.3390/foods10061382

Phan, T., Bremer, P., \& Mirosa, M. (2020). Vietnamese Consumers' Preferences for Functional Milk Powder Attributes: A Segmentation-Based Conjoint Study with Educated Consumers. Sustainability (Switzerland), 12(13), 1-16. https://doi.org/10.3390/su12135258

Prihanani, N. I., Ummami, R., Dalimunthe, N. W. Y., \& Ridlo, M. R. (2020). Evaluasi Kualitas Susu Kambing Etawa Yang Dikoleksi dari Peternakan Berskala Kecil Di Wilayah Samigaluh, Kulon Progo. Jurnal 
Nasional Teknologi Terapan (JNTT), 3(1), 41. https://doi.org/10.22146/jntt.56616

Pristawati, \& Fikri, M. H. (2021). Pengaruh Komunikasi Word Of Mouth dan Place Terhadap Keputusan Pembelian pada Usaha Susu Kambing Etawa Mulia Jaya. Jurnal Simki Economic, 4(1), 1-10.

Pusat Data dan Sistem Informasi Pertanian. (2019). Buku Outlook Komoditas Peternakan Susu Sapi.

Ranadheera, C. S., Evans, C. A., Baines, S. K., Balthazar, C. F., Cruz, A. G., Esmerino, E. A., Freitas, M. Q., Pimentel, T. C., Wittwer, A. E., Naumovski, N., Graça, J. S., Sant'Ana, A. S., Ajlouni, S., \& Vasiljevic, T. (2019). Probiotics in Goat Milk Products: Delivery Capacity and Ability to Improve Sensory Attributes. Comprehensive Reviews in Food Science and Food Safety, 18, 867-882. https://doi.org/10.1111/15414337.12447

Ratnamentari, W. S., Rahayu, E. S., \& Sundari, M. T. (2016). Analisis Perilaku Konsumen Susu UHT (Ultra High Temperature) di Pasar Swalayan Kota Surakarta. AGRISTA, 4(3), 405-413.

Resmawati, T., Mukid, M. A., \& Safitri, D. (2013). Analisis Preferensi Konsumen Terhadap Produk Susu Berbasis Analisis Conjoint Menggunakan Metode Presentasi Pairwise-Comparison. Jurnal Gaussian, 2(4), 405-414.

Santoso, S. I., Setiadi, A., Kisworo, A. N., \& Nuswantara, L. K. (2012). Analysis Various Factors that Influence the Purchasing Behavior of Goat Milk in Bogor Regency, Indonesia. International Journal of Engineering \& Technology IJET-IJENS, 12(05), 124-131. http://citeseerx.ist.psu.edu/viewdoc/summary?doi=10.1.1.419.7506

Shingh, S., Yadav, O. P., Ghimire, S., \& Dahal, N. (2020). Analysing the Consumer Preference of Fluid Milk in Province no. 2 of Nepal. Archives of Agriculture and Environmental Science, 5(3), 377-383. https://doi.org/10.26832/24566632.2020.0503020

Shunekeyeva, A. A. (2020). Research of Preferences of Consumers of Dairy Products in the Akmola region. EurAsian Journal of BioSciences, 14(January), 6687-6690.

Solikah, U. N., \& Dewi, T. R. (2016). Analisis Perilaku Konsumen Dalam Membeli Susu Instan Di Kota Surakarta. Agronomika, 10(02), 59-70.

Šugrová, M. (2018). Consumer Behaviour on the Market of Dairy Products: Case Study of Slovak Seniors. 544-556. https://doi.org/10.15414/isd2018.s2-2.03

Tarigan, H. A. M., Zakaria, W. A., \& Nugraha, A. (2020). Analisis Biaya Pokok Produksi dan Pendapatan Usaha Susu Kambing Peranakan Etawa (Studi Kasus pada Kelompok Ternak Maju Jaya di Kecamatan Batanghari Kabupaten Lampung Timur). JIIA, 8(3), 490-495.

Tekea, M. E. (2021). Review on Consumer Preference of Milk and Milk Product in Ethiopia. International Journal of Horticulture, Agriculture and Food Science, 5(2), 1-8. https://doi.org/10.22161/ijhaf.5.2.1

Tuan, L. T., Phuong, N. T. T., Ngoc, L. T. B., \& Mai, L. H. (2013). Powdered Milk Consumers' Buying Behavior. International Journal of Business and Management, 8(2), 29-37. https://doi.org/10.5539/ijbm.v8n2p29

Velcovská, Š., \& Larsen, F. R. (2021). The Impact of Brand on Consumer Preferences of Milk in Online Purchases: Conjoint Analysis Approach. Acta Universitatis Agriculturae et Silviculturae Mendelianae Brunensis, 69(3), 345-356. https://doi.org/10.11118/actaun.2021.032

Widaryanti, W. B., \& Retnaningsih. (2018). Analysis Of Milk Consumption Behavior and Processed Products on IPB Students with AIDA and CRI Methods. Journal of Consumer Sciences, 3(1), 50. https://doi.org/10.29244/jcs.3.1.50-64

Widodo, Rachmawati, A. V., Chulaila, R., \& Budisatria, I. G. S. (2012). Produksi dan Evaluasi Kualitas Susu Bubuk Asal Kambing Peranakan etawa (PE). J. Teknol. Dan Industri Pangan, XXIII(2), 132-139. https://doi.org/10.6066/jtip.2012.23.2.132

Wijesinghe, A. G. K., Abeynayake, N. R., \& Priyadarshani, R. L. C. (2020). Factors Influencing Milk Powder 
Brand Preference: A Case from Kegalle District of Sri Lanka. Sri Lanka Journal of Marketing, 6(2), 1. https://doi.org/10.4038/sljmuok.v6i2.40

Yang, T., \& Dharmasena, S. (2020). Consumers Preferences on Nutritional Attributes of Dairy- alternative Beverages: hedonic pricing models. Food Science \& Nutrition, 8(June), 5362-5378. https://doi.org/10.1002/fsn3.1757

Yasmin, T. R., Prastiwi, W. D., \& Handayani, M. (2017). Analisis Konjoin Preferensi Konsumen Sayuran Hidroponik Agrofarm Bandungan Kabupaten Semarang. Agrisocionomics: Jurnal Sosial Ekonomi Pertanian, 1(1), 85. https://doi.org/10.14710/agrisocionomics.v1i1.1643 